\title{
Redescription, geographic distribution and ecological niche modeling of Elapomorphus wuchereri (Serpentes: Dipsadidae)
}

Omar Machado Entiauspe-Neto, ${ }^{1}$ Márcia Ferret Renner, ${ }^{2}$ Conrado Mario-da-Rosa, ${ }^{3}$ Arthur Diesel Abegg, ${ }^{4}$ Daniel Loebmann, ${ }^{1}$ and Thales de Lema ${ }^{2}$

${ }^{1}$ Laboratório de Vertebrados, Instituto de Ciências Biológicas, Universidade Federal do Rio Grande, Av. Itália km 8, Vila Carreiros, 96203-900, Rio Grande, RS, Brazil. E-mail: omarentiauspe@ hotmail.com.

${ }^{2}$ Laboratório de Herpetologia, Museu de Ciências e Tecnologia da Pontifícia Universidade Católica do Rio Grande do Sul, Av. Ipiranga 6681, Partenon, 90619-900, Porto Alegre, RS, Brazil.

${ }^{3}$ Laboratório de Biologia Evolutiva, Universidade Federal de Santa Maria, Av. Roraima, 1000, Camobi, 97105-900, Santa Maria, RS, Brazil.

${ }^{4}$ Laboratório Especial de Coleções Zoológicas, Instituto Butantan, Av. Vital Brasil, 1500, Butantã, 05503-900, São Paulo, SP, Brazil.

\begin{abstract}
Redescription, geographic distribution and ecological niche modeling of Elapomorphus wuchereri (Serpentes: Dipsadidae). The original description of Elapomorphus wuchereri Günther, 1861 included a drawing and brief comments about the morphology of three specimens; two of the latter belong to another species and the holotype is lost. Based on the discovery of new specimens, we redescribe Elapomorphus wuchereri and designate a neotype. We discuss the variation and the taxonomic history of the species, and based on the results of a species distribution model analysis (SDM), we describe the distribution, extent of occurrence, and conservation status.
\end{abstract}

Keywords: Atlantic Forest, coloration, Groundsnake, morphology, taxonomy, variation.

\begin{abstract}
Resumo
Redescrição, distribuição geográfica e modelagem de nicho ecológico de Elapomorphus wuchereri (Serpentes: Dipsadidae). A descrição original de Elapomorphus wuchereri Günther, 1861 continha um desenho e comentários breves acerca da morfologia de três espécimes; dois destes pertencem a outra espécie e o holótipo está perdido. Com base na descoberta de novos espécimes, redescrevemos Elapomorphus wuchereri e designamos um neótipo. Discutimos a variação e o histórico taxonômico da espécie e, com base nos resultados de uma modelagem de nicho ecológico (SDM), descrevemos sua distribuição, extensão de ocorrência e status de conservação.
\end{abstract}

Palavras-chave: cobra-da-terra, coloração, Floresta Atlântica, morfologia, taxonomia, variação.

Received 05 December 2016

Accepted 22 June 2017

Distributed December 2017 


\section{Introduction}

Elapomorphini is a clade of mainly fossorial, small- to medium-sized dipsadid snakes, that includes Apostolepis Cope, 1861, Coronelaps Lema and Hofstadler-Deiques, 2010, Elapomorphus Wiegmann (in Fitzinger), 1843, and Phalotris Cope, 1862 (Ferrarezzi 1993, Hofstadler-Deiques and Lema 2005, Lema and Hofstadler-Deiques 2010). These snakes are widely distributed in forested and open biomes across most of South America east of the Andes, from Colombia and French Guiana to Argentina (Ferrarezzi 1993).

The genus Elapomorphus occurs almost exclusively in the Atlantic Forest Biome (sensu Galindo-Leal and Câmara 2005) and contains two species. Elapomorphus quinquelineatus (Raddi, 1820) ranges from the state of Rio de Janeiro in southeastern Brazil to the state of Rio Grande do Sul in southern Brazil. Elapomorphus wuchereri Günther, 1861, is recorded from the states of Bahia and Espírito Santo (Lema and Hofstadler-Deiques 2010). Until recently, the monotypic genus Coronelaps lepidus (Reinhardt, 1861) was included in Elapomorphus; the description of this taxon was based on a specimen collected in the state of Minas Gerais in southeastern Brazil and included notes on its coloration in life, with emphasis on the yellow nape collar that distinguishes it from the two former species.

Since the formal description of Elapomorphus wuchereri, the species has had a convoluted taxonomic history. Günther's (1861a) brief description includes illustrations of three individuals - a larger specimen (possibly BMNH.1946.1.2.96), and two young individuals (BMNH.1946.1.2.92 and BMNH.1946.3.1). The two latter specimens were identified as Coronelaps lepidus by Lema and Hofstadler-Deiques (1995).

Although a few authors recognized Elapomorphus wuchereri, there was no consensus as to the distinguishing features of the species. Jan (1862) described Elapomorphus accedens Jan, 1862 and designated a holotype from "Bahia," without indicating where the type was deposited or providing precise locality data. In the same work, Jan suggested that E. accedens might be a variant of Elapomorphus blumii Strauch, 1884 (now a synonym of E. quinquelineatus), although he noted that it also resembled Coronelaps lepidus. Strauch (1884) redescribed E. wuchereri based on the same specimens that Günther (1861a) used; he noted the morphological resemblance of E. wuchereri to E. quinquelineatus, and reported that the holotype of E. accedens came from the vicinity of "Salvador, Bahia," was morphologically close to E. wuchereri, and was housed in the Staatlisches Museum für Naturkunde (SMS, Sttutgart, Germany).

In his revision of "Elapomorphus lato sensu" Boulenger (1896) considered three species to be valid: Elapomorphus lepidus Reinhardt, 1861; E. wuchereri; and Apostolepis coronata (Sauvage, 1877) (originally described as Elapomorphus and currently a synonym of Coronelaps lepidus). He designated two specimens (referred to as "A" and "B," but now BMNH.1946.1.2.92 and BMNH.1946.3.1) as syntypes of E. lepidus; he identified four other specimens as E. wuchereri (viz., "A," "B," "C," and "D"), with A and B (now BMNH 1946.1.2.91 and BMNH.1946.1.2.96) as syntypes.

Amaral (1930a) suggested that Elapomorphus wuchereri was a junior synonym of E. lepidus, and designated Apostolepis quinquelineata Boulenger, 1896 and A. pymi Boulenger, 1903 as synonyms of $A$. coronata. Overlooking the works of Amaral (1930a,b,c, 1935, 1936), Peters and Orejas-Miranda (1970) considered E. wuchereri, E. lepidus, and A. coronata to be valid species, but they retained $E$. accedens as a synonym of $E$. wuchereri. Cunha and Nascimento (1978) revalidated A. pymi and A. quinquelineata from the synonymy of $A$. coronata. Lema and Hofstadler-Deiques (1995) re-examined the type series of E. wuchereri, and concluded that two of the snakes were Elapomorphus lepidus and that $E$. wuchereri was a synonym of $E$. quinquelineatus. In a brief revision based on external and internal morphology, Lema and HofstadlerDeiques (2010) erected the monotypic genus 
Coronelaps for Elapomorphus lepidus, while also revalidating $E$. wuchereri, until then a synonym of $E$. quinquelineatus. No other revisions of Elapomorphus or descriptions of variation in the genus have appeared since.

Herein, we redescribe Elapomorphus wuchereri based on examination of morphology, and intraspecific and ontogenetic variation in both living and preserved specimens. Comparisons are made with its congener, $E$. quinquelineatus. We also comment on the known distribution of $E$. wuchereri, present a species distribution model, and discuss on the conservation status of the species.

\section{Materials and Methods}

\section{Taxonomy}

We examined 13 (two unvouchered) specimens of Elapomorphus wuchereri, $187 \mathrm{E}$. quinquelineatus and 38 Coronelaps lepidus from the following collections: BMNH, The Natural History Museum, London, U.K.; CZGB, Coleção Zoológica Gregório Bondar, Ilhéus, Brazil; FMNH, Field Museum, Chicago, USA; FUNED, Fundação Ezequiel Dias, Belo Horizonte, Brazil; IBSP, Instituto Butantan, São Paulo, Brazil; IPSP, Instituto Pinheiros, Produtos Terapêuticos S.A., São Paulo, Brazil; MBES, Museu de Biologia "Mello Leitão," Santa Teresa, Brazil; MCTP, Museu de Ciências e Tecnologia, Porto Alegre, Brazil; MCZ, Museum of Comparative Zoology, Cambridge, USA; MNHN, Muséum National d'Histoire Naturelle, Paris, France; MNRJ, Museu Nacional, Rio de Janeiro, Brazil; MZUFV, Museu de Zoologia João Moojen, Universidade Federal de Viçosa, Brazil; MSNM, Museo Civico di Storia Naturale di Milano, Italy; MZUSP, Museu de Zoologia da Universidade de São Paulo, São Paulo, Brazil; MZUT, Museo di Zoologia, Universitá di Torino, Italy; NMW, Naturhistorisches Museum zu Wien, Austria; SMS, Staatlisches Museum für Naturkunde, Sttutgart, Germany; UESCB, Universidade Estadual de Santa Cruz, Ilhéus,
Brazil; USNM, United States National Museum, Washington, DC, USA; ZISP, Rossíiskaya akadémiya naúk Saint Petersburg, Russia; ZMB, Zoologisches Museum zu Berlin, Germany; ZUEC, Museu de Zoologia, Universidade Estadual de Campinas, Brazil.

Head measurements were taken with a dial or digital caliper to the nearest $0.1 \mathrm{~mm}$, whereas others were taken with a flexible ruler. Unless otherwise stated, measurements follow follow those of Lema and Hofstadler-Deiques (1995). Ventral scales were counted as per Dowling (1951). Taxonomic accounts follow Dubois (2000). Sex determination was made by a small incision at the base of ventral side of tail, exposing the hemipenis (males), or the anal glands (females).

\section{Distribution and Modeling}

The range of Elapomorphus wuchereri was considered to be the area contained within the shortest continuous imaginary boundary, drawn to encompass all known, inferred, or projected sites of present occurrence (IUCN 2012, 2014). To calculate the range, we employed a minimum convex polygon method that consists of drawing a polygon that contains all sites of occurrence for the species (sensu IUCN 2012, 2014) and in which the internal angles do not exceed $180^{\circ}$. Then, we created a binary presence/absence species distribution map based on the "Equal training sensitivity and specificity" threshold within the software R 3.3.3. (R Development Core Team 2008) and the $\mathrm{R}$ package dismo (Hijmans et al. 2013), and visualized in the ArcMap software (ESRI 2014). Habitat loss was calculated with the use of a current Atlantic Forest remnants shapefile, while we also included a shapefile containing strictly protected areas (also known as Conservation Units in Brazil, equivalent to IUCN Categories I, II, and III) within the Atlantic Forest.

To evaluate the suitability of possible areas in which Elapomorphus wuchereri might occur, we implemented a species distribution modelling 
(SDM) technique that was based on 10 locality records obtained from literature and museum records (Table 1); unless a location description was explicit, coordinates were taken from the respective county or municipality seat. We used the DIVA-GIS database (http://www.diva-gis. org/gdata) to download the map shapefiles used. The area of the range was defined with a polygon with Google Earth ${ }^{\odot}$ with coordinates set between $08^{\circ} 04^{\prime} 31.79^{\prime \prime} \mathrm{S}$ and $25^{\circ} 03^{\prime} 56.57^{\prime \prime} \mathrm{S}$ and between $51^{\circ} 40^{\prime} 7.17^{\prime \prime} \mathrm{W}$ and $35^{\circ} 24^{\prime} 15.16^{\prime \prime} \mathrm{W}$, which encompasses the limits of the southeastern Brazilian Atlantic Forest Biome in which the species is endemic; the polygon was then transformed into a layer, to extract the climatic data.

The SDM of Elapomorphus wuchereri was conducted under current climatic conditions; we applied bioclimatic variables of the WorldClim Project (Hijmans et al. 2005), with a resolution of 30 arc seconds $(\sim 1 \mathrm{~km})$. Then, we used the software R 3.3.3. (R Development Core Team 2008) with the $\mathrm{R}$ package dismo (Hijmans et al. 2013), both in standard configurations, to test the variables for their significance. The following uncorrelated variables $(\mathrm{r}>0.7)$ were selected (Phillips et al.
2006): Bio 3-Isothermality; Bio 4-Temperature Seasonality; Bio 7-Temperature Annual Range; Bio 10-Mean Temperature of Warmest Quarter; Bio 11-Mean Temperature of Coldest Quarter; Bio 14-Precipitation of Driest Month; Bio 15Precipitation Seasonality; Bio 16-Precipitation of Wettest Quarter; Bio 17-Precipitation of Driest Quarter and Elevation.

We generated a potential distribution model of Elapomorphus wuchereri based on the nine parameters selected and the occurrence data of the species, using the maximum entropy algorithm of the MaxEnt 3.3.3k software (Phillips et al. 2006, Phillips \& Dudik 2008). Random test percentage was set to $25 \%$ of the input occurrence records of the species, selected by cross-validation to test the performance of the resulting model. We also ran 15 replications with AUC > 0.7 (Area Under the Receiver Operator Curve), a rank-correlation measure that when high, indicates that sites with high predicted suitability values usually are likely to have the putative species present, whereas those with lower values are less likely to have the species (Hijmans and Elith 2017). We calculated the mean of these AUC cross-validations to test the predictive performance of the model. The

Table 1. Vouchered locality records of Elapomorphus wuchereri used in this study.

\begin{tabular}{lcccc}
\hline State & Municipality (locality) & Latitude & Longitude & Source of record \\
\hline Bahia & Porto Seguro (RPPN Estação Veracel) & -16.3500 & -39.1333 & IBSP.55983 \\
Bahia & Ilhéus & -14.7833 & -39.0333 & BMNH.1946.1.2.91 \\
Bahia & Ilhéus (Salto do Apepique) & -14.6167 & -39.1333 & UESCB.4288 \\
Bahia & Mucuri (Fazenda Pombal) & -18.1000 & -39.6167 & ZUEC.240 \\
Bahia & Mutuipe & -13.2167 & -39.5000 & UESCB.1457 \\
Bahia & Valença & -13.3667 & -39.0667 & Freitas (2014) \\
Espírito Santo & Baixo Guandú & -19.5333 & -41.0167 & IBSP.8825 \\
Espírito Santo & Linhares & -19.3833 & -40.0500 & MZUSP.9837 \\
Espírito Santo & Sooretama & -19.1500 & -40.0500 & Bérnils et al. (2014) \\
Minas Gerais & (Reserva Biológica Sooretama) & -16.3167 & -40.1000 & MZUFV.1205 \\
\hline
\end{tabular}


resulting suitability model then was projected onto a geographical map, with the results interpreted as areas with suitable climate for the occurrence of the species (Nóbrega et al. 2016); these areas range from 0 (unsuitable) to 1 (highly suitable).

\section{Results}

\section{Taxonomy}

\section{Elapomorphus wuchereri Günther, 1861}

Elapomorphus wuchereri Günther, 1861a (partim): 15. Original name-bearing type: the larger specimen illustrated in Günther (1861a: 16), considered lost. Type locality: Rio Ilhéus, Ilhéus, Bahia, Brazil. Other original types: BMNH 1946.1.2.92 (or) and BMNH 1946.1.3.1 (ㅇ) (Figure 1); the two smaller specimens illustrated in Günther (1861a) are current syntypes of a different taxon, Coronelaps lepidus (Reinhardt, 1861). Current name-bearing type: Neotype, BMNH.1946.1.2.91 (우 Figure 2). Type locality: Cacao farm, Rio Ilhéus, Ilhéus, Bahia, northeastern Brazil.

Elapomorphus wuchereri Günther, 1861b (partim): 415. A reprint of Günther (1861a). Elapomorphus wuchereri - Strauch, 1884 (partim); Strauch, 1885 (reprint of Strauch 1884); Boulenger, 1896 (partim); Peters and Orejas-Miranda, 1970; Lema, 1984 (partim); Argôlo, 2004; Lema and Hofstadler-Deiques, 2010; Hamdan and Lira-da-Silva, 2012; Freitas, 2014; Bérnils et al. 2014.

Heterochresonymy:

Coronelaps (Elapomorphus) lepidus [non Elapomorphus lepidus Reinhardt, 1861] - Amaral, 1930; Lema and Hofstadler-Deiques, 1995 (partim).

Elapomorphus quinquelineatus [non Coluber 5-lineatus Raddi, 1820] Lema and Hofstadler-Deiques, 1995 (partim).
We designate a neotype to clarify the status of Elapomorphus wuchereri Günther, 1861 in its current definition (Art. 75.3.1 of the Code). The species was described based on three specimens, and it is unclear whether a holotype was designated from the series; a redescription of $E$. wuchereri follows (Art. 75.3.2).

Boulenger (1896) designated the specimen BMNH 1946.1.2.96 as a syntype of Elapomorphus wuchereri. It should be noted that the ventral and subcaudal counts of the specimens described by Günther (1861a) and Boulenger (1896) are not the same. It is possible that BMNH.1946.1.2.96 is the "female, large specimen [...] with 181 ventral and 32 subcaudal shields" of Günther (1861a) and the "D" specimen of Boulenger (1896) because Boulenger indicated that the " $\mathrm{D}$ " individual is a female that has " 181 ventrals and 34 subcaudals." The fate of the "A," " $B$," and "C" specimens is unclear, although BMNH 1946.1.2.91 (179 ventrals and 33 subcaudals) closely resembles the descriptions of Boulenger's (1896)"A" specimen, which he described as having "179 ventrals and 35 subcaudals."

We are not able to determine if BMNH.1946.1.2.96 belongs to the original type series and whether Gunther designated a holotype. In following the recommendation of the Code not to assume the designation of a holotype (Art. $73.73 \mathrm{~F}$ ), we designate a neotype instead of a lectotype, given the conflicting descriptions and museum information. We have selected a specimen matching the description of Günther (1861a) (Art. 75.3.5) and resembling the syntype designated by Boulenger (1896); the latter also is a topotype (Art. 75.3.6). We designate a wellpreserved specimen (BMNH.1946.1.2.91) as the neotype of Elapomorphus wuchereri and base our diagnosis on it to assist in maintaining taxonomic stability within the Elapomorphini (as per Art. 75.3.7 of the Code).

Redescription of the type specimen.-Neotype: BMNH.1946.1.2.91 (Figure 2, formerly BMNH.61.3.23.7) an adult female from a Cacao 


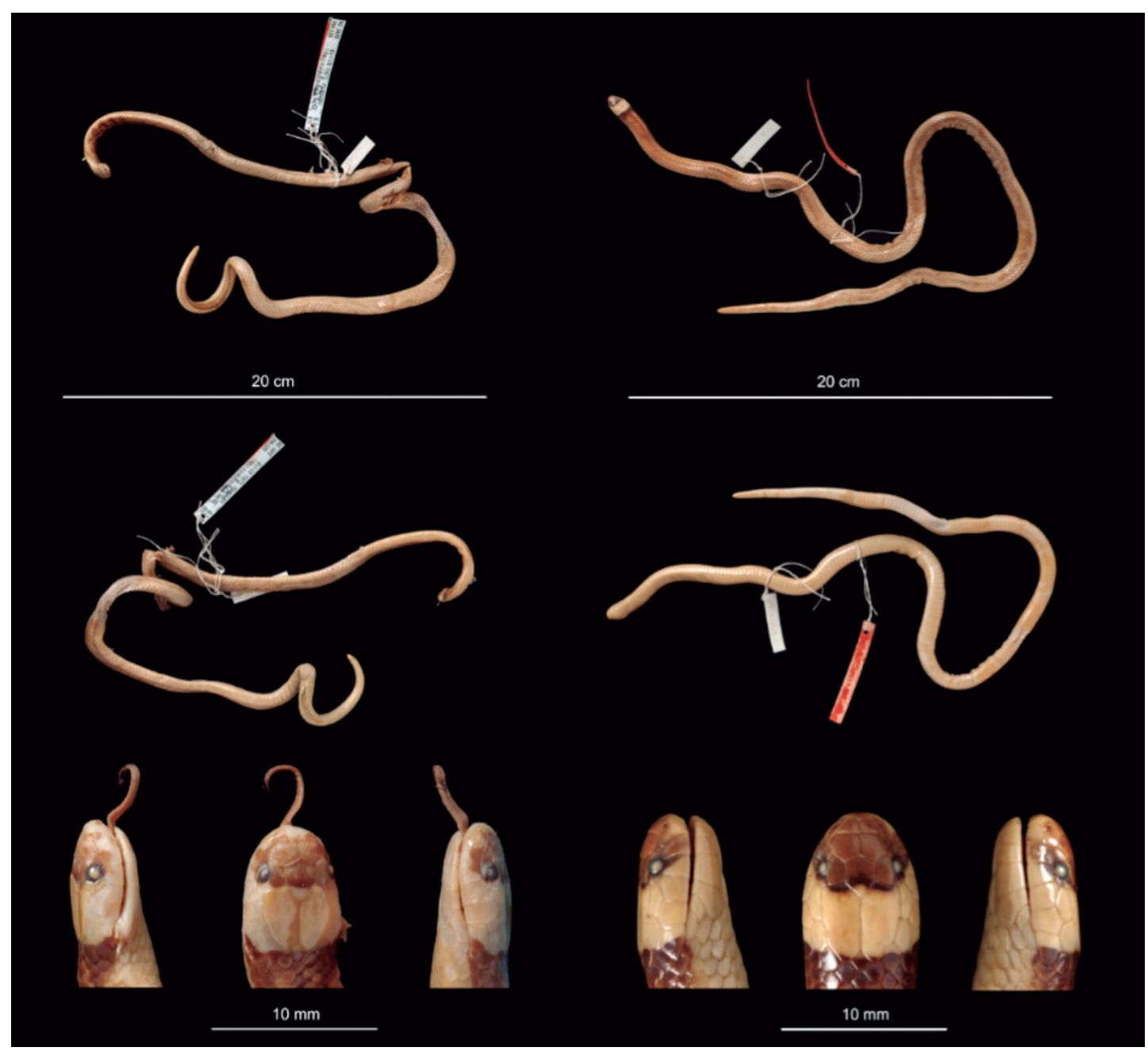

Figure 1. Syntypes of Coronelaps lepidus (left, BMNH 1946.1.2.92; right, BMNH 1946.1.3.1). Photo credits: Patrick Campbell.

Farm, Ilhéus River, Ilhéus, Bahia, northeastern Brazil, $\left(-15.7833^{\circ},-39.0333^{\circ}\right)$. Captured by Otto Wucherer, 1860.

Morphology.-Head robust, broad, and dorsoventrally flattened; head wider than long; neck with same diameter as head; snout rounded, without canthus rostralis. Eyes small, oriented anteriorly, visible from above, eye diameter three times its distance to lip; iris black, pupil broad, elliptical. Nostrils anterior in nasal, turned forward. Snout round andflat on dorsal view. Trunk thick in anterior third, becoming slender posteriorly, subcylindrical, slightly depressed. Tail more slender than trunk, tapering to tip; slightly conical terminal spine.

Measurements (in mm).- Snout-vent length, 1212.7; head length, 21; trunk length, 1191; tail length, 114.4; head width, 19 (measured at 


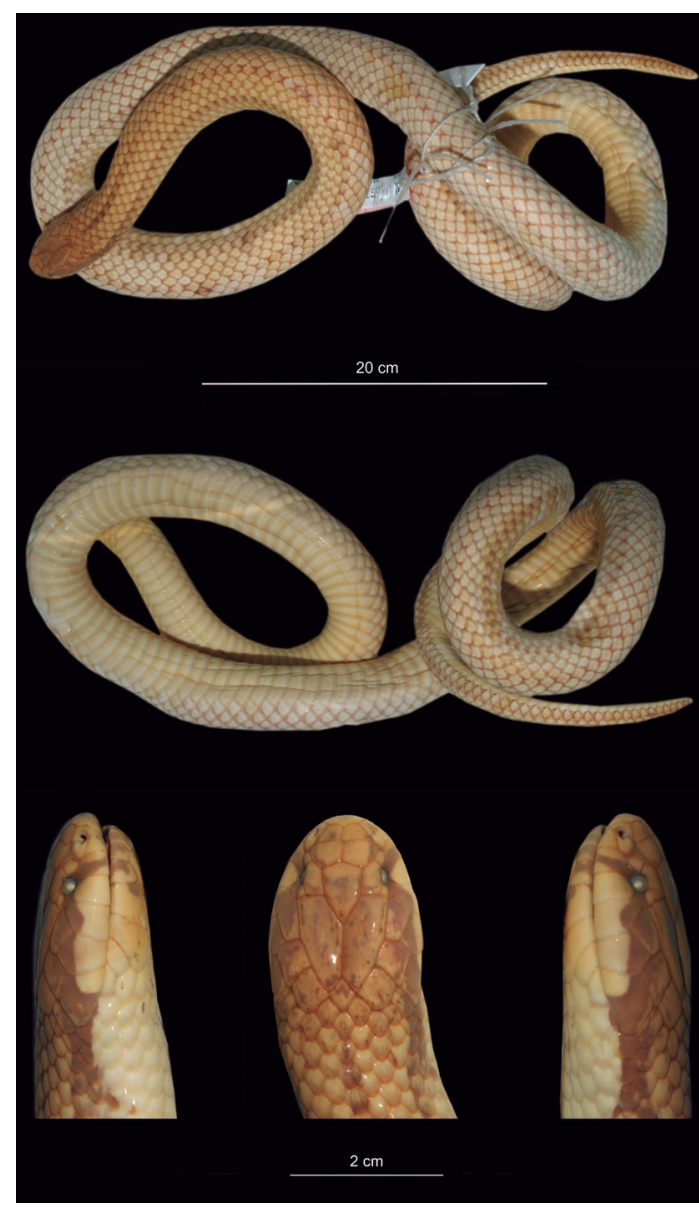

Figure 2. Neotype of Elapomorphus wuchereri (BMNH. 1946.1.2.91). Photo credits: Jeffrey Streicher.

parietals), 5.5 (measured at nostrils); head height, 13 (measured at parietals), 6 (measured at nostrils); eye diameter, 1 ; trunk diameters - 16 at neck, 19 at midbody, 16 at posterior third, 12 at pre-cloacal; tail diameter 10 at base, 8 at midpoint, 4 at pre-terminal spine.

Pholidosis.-Rostral scale wider than long; slightly projecting, with small tongue groove; portion of rostral visible from above greater than half of internasal suture. Internasal narrow, asymmetrical, trapezoidal, with right suture; slightly shorter than prefrontal, wider than long. Prefrontal longer than broad, twice the size of internasal. Preocular single, smaller than nasal, larger than orbit, pentagonal, smaller than postocular. Two postoculars, pentagonal, subequal to preocular. Upper postocular higher than wide, in contact with parietal and anterior temporal. Lower postocular wider than high, in contact with anterior temporal. Nasal triangular, higher anteriorly and narrow posteriorly, in contact with preocular, smaller than orbit. Frontal pentagonal, slightly tapered posteriorly, half of parietal length, longer than broad. Supraoculars small, short, and rectangular. Parietals narrow and long, length equal to half of head length, with sharp apex, width equal to $1 / 4$ of head width, in contact with postoculars, with small vertical suture. Occipital scale large and rhomboid, similar to anterior temporal and dorsal scales, but about four times larger. Supralabials 6 , increasing in size posteriorly; $2^{\text {nd }}$ and $3^{\text {rd }}$ in contact with orbit; $1^{\text {st }}$ triangular, smallest; $3^{\text {rd }}$ and $4^{\text {th }}$ highest, both narrow and in contact with orbit; $6^{\text {th }}$ equal to posterior temporal on right side, fused with a dorsal on left side. Temporals $1+1$. Posterior temporal wider and higher than anterior temporal, in contact with occipital. Mental small, triangular, broader than long. Infralabials $7 ; 4^{\text {th }}$ and $5^{\text {th }}$ large; $6^{\text {th }}$ and $7^{\text {th }}$ small, elongate, rectangular; $1^{\text {st }-4^{\text {th }}}$ in contact with anterior chinshields; $5^{\text {th }}$ contacting posterior chinshields. Dorsal scale rows 15, smooth; preventrals 2; ventral scales 179; subcaudals in 33 pairs, cloacal scale divided.

Coloration of neotype in preservative.-Top of head medium brown. Dark brown stripe on lateral head, extending to rostral, internasals, prefrontals, preoculars, second and third supralabials and upper part of posterior supralabials; stripe continues posteriorly as dorsolateral body stripe. Rostral with a central black triangular blotch. Posterior supralabials white. Gular region is light brown, with several irregular dark brown blotches extending from 
the mental groove onto infralabials and chinshields. Scattered small black dots on mental scales, $5^{\text {th }}$ and $6^{\text {th }}$ infralabials, and gulars. Three dorsal dark brown stripes, vertebral stripe faint, faded; lateral stripes with minute black spots, except in the paraventral zone with a wide darker band. Ventral trunk and tail uniform cream.

Diagnosis.-Elapomorphus wuchereri can be distinguished from all its congeners by the following combination of characters: (1) dorsal scales 15-15-15, smooth; (2) postoculars two; (3) loreal absent; (4) temporals $1+1$; (5) six supralabials, $2^{\text {nd }}$ and $3^{\text {rd }}$ in contact with orbit; (6) seven supralabials; (7) gular scale rows 2-4; (8) ventrals 164-188 (179-188 in females, 164-169 in males); (9) subcaudals 30-46 (30-34 in females, 40-46 in males); (10) dorsal pattern with three narrow dorsal stripes in juveniles, and faint stripes in adults on a copper or yellow background; (11) ventral surface immaculate cream; (12) snout-vent length 194-1212 mm (194-1212.7 in females, 224.5-863.6 in males).

Comparisons.-Elapomorphus wuchereri is compared with E. quinquelineatus in Table 2 and Figure 3. Elapomorphus wuchereri differs from E. quinquelineatus (characters in parentheses) by absence of nape-cervical collars (present); ventral side of head uniformly colored (dotted), with black blotches radiating from mental groove (white background, with black circular blotches); background color varying during development, from copper to yellow (olive-brown to yellow); dorsal pattern from three narrow stripes in juveniles to faint stripes in adults ( 5 dark stripes reducing to 3). It is distinguished from Coronelaps lepidus by lacking a yellow parietal band and nape-cervical collars, and having a thicker body, and longer, more depressed head (rounded in $C$. lepidus), and fewer than 200 ventrals (more than 200 in C. lepidus).

Morphometric variation.-Measurements and counts are summarized in Tables 1 and 3 . Morphometric sexual dimorphism is evident.
The quantitative data show: (a) greater number of ventrals in females $(179-188, \overline{\mathrm{x}}=184.2 \pm$ $4.24, N=8)$ than males $(164-169, \overline{\mathrm{x}}=166 \pm$ $2.16, N=4)$; (b) more subcaudals in males (40$46, \overline{\mathrm{X}}=44.0 \pm 3.21, N=4)$ than females $(30-34$, $\overline{\mathrm{X}}=31.8 \pm 1.47, N=8$ ); (c) greater snout-vent length in females $(194-1212.7, \bar{x}=666.2 \pm$ $416.1, N=4)$ than males $(224.5-863.6, \overline{\mathrm{x}}=239$, $N=3$ ); (d) longer tails in males (48-152.4, $\overline{\mathrm{x}}=$ $48, N=3)$ than females $(20.5-122, \overline{\mathrm{X}}=90 \pm 45.2)$.

Meristic variation.-The part of rostral visible in dorsal aspect is equal to the length of the internasal suture in ZUEC.240; internasal and prefrontal sutures can be oblique or straight. Internasals of MZUSP.9837 and BMNH.1946. 1.2.91 are wider than long, and in IBSP.55983, half as large as the prefrontals. The frontal of ZUEC.240 and IBSP.8825 has curled lateral sides; a posterior angle is absent because the prefrontals are rounded in MZUSP.9837; in ZUEC.240, frontal length is less than half of parietal length. The supraocular of IBSP.55983 has a v-like parallelogram shape. Occipitals $2 / 2$ in ZUEC 240. In MZUSP.9837 the $5^{\text {th }}$ supralabial is high, short, oblique with a point extending between the temporals; in the same specimen, the $3^{\text {rd }}$ supralabial is long; supralabials oblique in other specimens. In IBSP.55983, the postoculars are asymmetrical. In ZUEC.240, the mental is longer than wide. The number of lateral gular scales varies from $5 / 5$ to $6 / 6$, but in IBSP.55983, there are 6/5. Median gulars vary from $3 / 3$ (IBSP.55983, BMNH.1946.1.2.91), 2/2 + 2 (IBSP.8825), 3/3 + 2 (MZUSP.937), and 4/4 (ZUEC.240). The cloacal is single in IBSP.55983.

Color in life.-This description is based on the examination of three uncollected specimens from Ilhéus and Valença, Bahia, Brazil (Figure 3 ). The head cap is dark brown, with irregular cream spots; the snout, labial, and gular regions are pale yellow. The vertebral zone is light brownish pink, the sides dark brown, the lowest 1 to 1.5 dorsal rows, in the paravertebral region, are pale yellow. The lateral sides of trunk and 
Table 2. Comparison of Elapomorphus species. Abbreviations Brazilian states: BA, Bahia; ES, Espírito Santo; PR, Paraná; RJ, Rio de Janeiro, RS, Rio Grande do Sul; SP, São Paulo; SC, Santa Catarina.

\begin{tabular}{|c|c|c|}
\hline Characters & Elapomorphus quinquelineatus & Elapomorphus wuchereri \\
\hline Tail diameter & Reducing from cloaca onwards & Reducing only near the tail tip \\
\hline Dorsal stripes & 5 to 3 , juvenile to adult & 3 to 0 , juvenile to adult \\
\hline Width of dorsal stripes & 1.5 to 2 dorsal rows & 0.5 dorsal row \\
\hline Paravertebral stripes & Shadowed in adult & Vestigial in nape collar \\
\hline Dark spots in sides of VE & Present sometimes & Absent \\
\hline Background color in newborn & Whitish & Copper color \\
\hline Background color in young & Brown & Pink \\
\hline Background color in early adult & Yellowish brown & Cinnabar \\
\hline Background color in adult & Yellow & Yellow \\
\hline White nape collar & Usually present, sometimes vestigial & Usually absent, sometimes vestigial \\
\hline Black cervical collar & Present, narrow, sometimes irregular & Absent \\
\hline Lower sides of trunk & Light bronze & Dark brown or yellow \\
\hline Mental black blotches & Circular, one by IL, near oral margin & Black radial short stripes \\
\hline Mental ground coloration & Light & Dark (shadowed and dotted) \\
\hline Distribution by states & BA (South), ES, RJ, SP, PR, SC, RS & BA, ES, MG (East) \\
\hline Ventral scales variation & $167-191$ & $179-206$ \\
\hline Subcaudal scales variation & $27-46$ & $30-46$ \\
\hline
\end{tabular}

Table 3. Meristic data of Elapomorphus wuchereri. Abbreviations: 1-11, specimens (1, Jan (1862) + Strauch (1884); 2, IBSP.55983; 3, MBES.77; 4, uncollected specimen from Ilhéus, Bahia, Brazil (Figure 3B); 5, BMNH.1946.1.2.91 (neotype); 6, BMNH.1946.1.2.96; 7, MZUSP.9837; 8, ZUEC.240; 9, IBSP.8825; 10, IBSP.9837, 11 uncollected specimen from Valença, Bahia, Brazil (Figure 3A). F, female; HE, head length; $M$, male; SVL, snout-vent length; Sp, specimens (vertical, see 1-11, above); TAL, tail length; TOL, total length; TRL, trunk length; VE, ventral scales.

\begin{tabular}{lcccccccc}
\hline Specimens & Sex & VE & SC & HE $(\mathbf{m m})$ & TRL $(\mathbf{m m})$ & SVL $(\mathbf{m m})$ & TAL $(\mathbf{m m})$ & TOL $(\mathbf{m m})$ \\
\hline 1 & M & 164 & 45 & - & - & 863.6 & 152.4 & 1016 \\
2 & M & 165 & 46 & 9 & 230 & 239 & 48 & 287 \\
3 & M & 169 & 40 & 9.5 & 215 & 224.5 & 39.5 & 264 \\
4 & M & 166 & 43 & - & - & - & - & - \\
5 & F & 181 & 32 & 21 & 1191 & 1212.7 & 114.4 & 1327 \\
6 & F & 179 & 33 & 21 & - & - & - & 122 \\
7 & F & 179 & 34 & 35 & 1165 & 1200 & 1322 \\
8 & F & 188 & 31 & 8 & 186 & 194 & 20.5 & 215.5 \\
9 & F & 188 & 30 & 16 & 550 & 566 & 58 & 624 \\
10 & F & 185 & - & 19 & 686 & 705 & - & - \\
11 & F & 188 & 31 & - & - & - & - \\
\hline
\end{tabular}



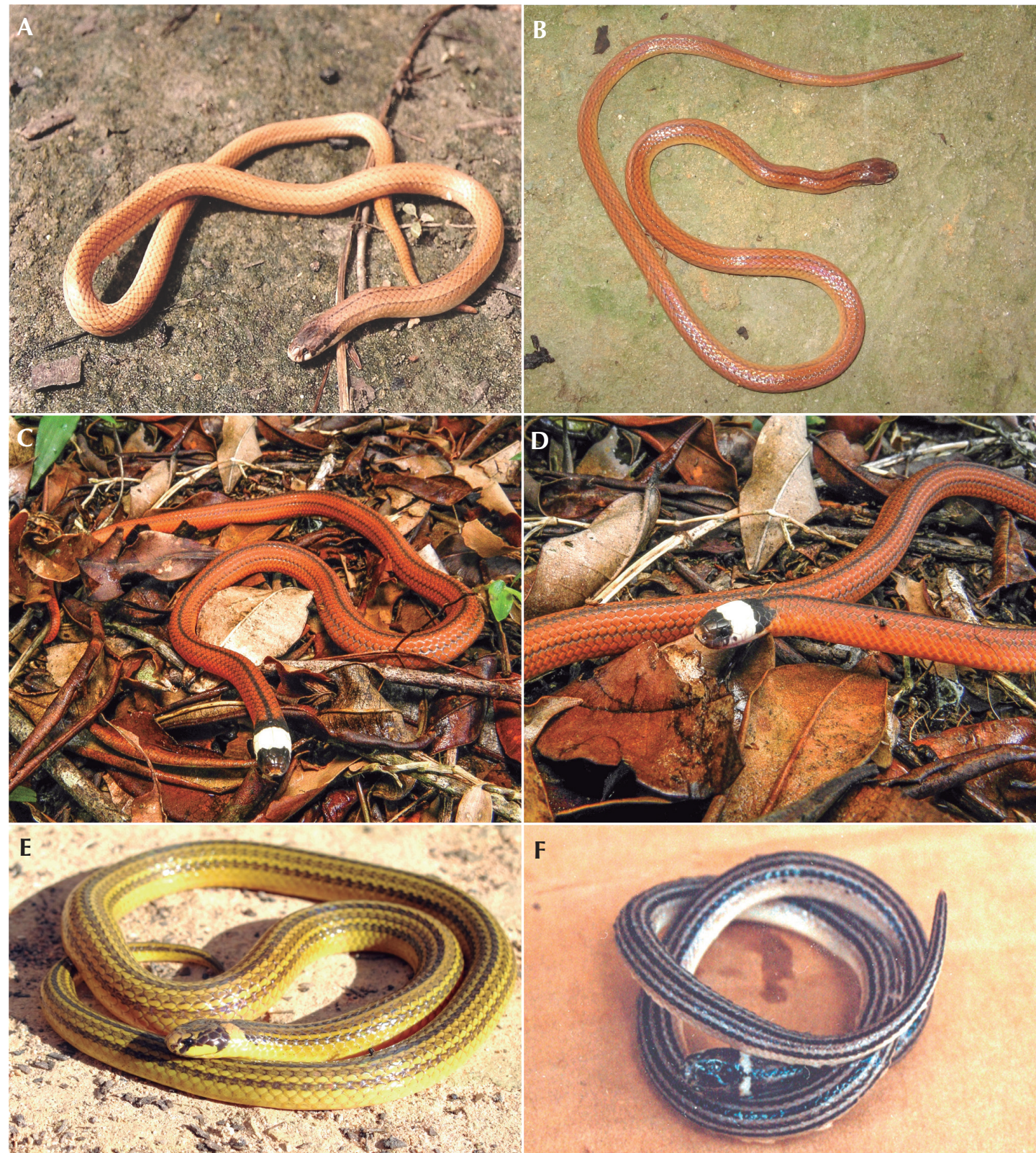

$F$

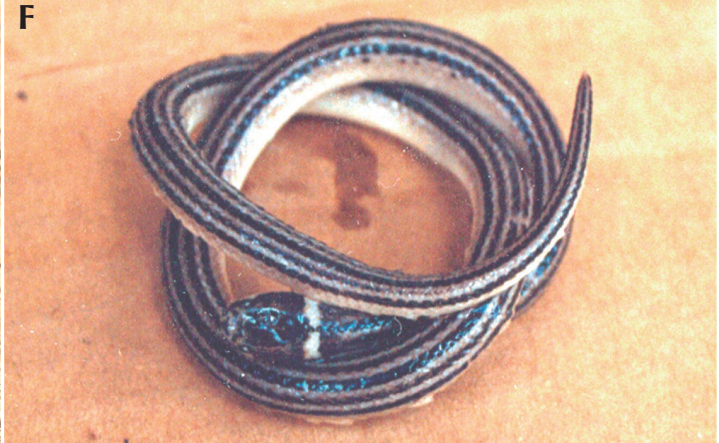

Figure 3. Species of Coronelaps and Elapomorphus examined in this study. (A) E. wuchereri from Valença, Bahia state (unvouchered). (B) E. wuchereri from Ilhéus, Bahia state (unvouchered). (C-D) C. lepidus from Araponga, Minas Gerais state (MZUFV 1871). (E) E. quinquelineatus from Morro do Pilar, Minas Gerais state (unvouchered). (F) E. quinquelineatus from Pedra Azul, Espírito Santo state (unvouchered). Photo credits: Marco Antonio de Freitas (A,B,F), Mário Ribeiro de Moura (C,D) and Pedro Henrique Martins (E). 
tail are yellowish white. The longitudinal stripes are faint, with the vertebral stripe being the most conspicuous. A black line is located on the anterior margins of the scales, starting across the nostril, below the eye and along the dorsal margin of supralabials, crossing $4^{\text {th }}$ supralabial vertically, forming an arc that ends at the lip (anterior corner of the $6^{\text {th }}$ supralabial); this line extends posteriorly as the lateral black stripe of the trunk and tail. The gular surface is light brown, with indistinct irregular black blotches. Some specimens have a large black blotch on the $4^{\text {th }}$ infralabial, similar to that of E. quinquelineatus. In some individuals, small dark spots are present on the $1^{\text {st }}$ row of dorsals, and resemble a vestigial stripe.

Ontogenetic variation.-Young individuals have black dorsal stripes, and faint paravertebral stripes on a copper ground color. The snout is white, bordered with black and the frontal has a black median stripe. Outer margins of prefrontals and inner margins of supraoculars are black; these black margins are small blotches in the youngest individuals. In older juveniles, the copper color is faded and stripes are weakly defined; they are absent in adults, which have a cinnabar coloration. The red dorsal color of juveniles fades to a uniform pinkish hue that is replaced by ocher and then yellow in mature adults. A newly hatched juvenile (IBSP.55983) has a pair of light blotches reminiscent of a vestigial white collar in the nape region.

\section{Distribution and Modeling}

According to current records, Elapomorphus wuchereri occurs in the Atlantic Forest Biome from northern Espírito Santo and east-central Bahia states to lowland rainforest in eastern Minas Gerais (Figure 4). The species seems to be absent from coastal areas (Antônio S. Argôlo, pers. comm.).

Models of climatically suitable areas reached a high prediction value (AUC $=0.919 ; \mathrm{SD}=$ 0.047; Phillips et al. 2006). The suitability threshold under the "Equal training sensitivity and specificity" metric is 0.125 . The binary presence/absence distribution suitability map (Figure 5) based on this threshold shows a continuous suitable area from northern (state of Alagoas) to the southeastern Atlantic Forest (São Paulo) and is similar to our climatically suitable area map (Figure 6). The bioclimatic variables Bio-15 (Precipitation Seasonality), Bio-14 (Precipitation of Driest Month), Bio-7 (Temperature Annual Range) and Bio-3 (Isothermality) contributed the most to the model $(85.3 \%$ of the model result contribution; Table 4).

Our species distribution model (Figure 6) indicates high habitat suitability for most of coastal Bahia and Espírito Santo, as well as for the states of Rio de Janeiro and São Paulo, with a gradual decrease in habitat suitability in the western parts of these states. It is noteworthy that Elapomorphus wuchereri has yet to be recorded in Rio de Janeiro or in São Paulo;

Table 4. Mean predictive performance, probability threshold and percent contributions of the predictor variables for the MaxEnt model used in this study. Variables: Bio 3 (Isothermality); Bio 4 (Temperature Seasonality); Bio 7 (Temperature Annual Range); Bio 10 (Mean Temperature of Warmest Quarter); Bio 11 (Mean Temperature of Coldest Quarter); Bio 14 (Precipitation of Driest Month); Bio 15 (Precipitation Seasonality); Bio 16 (Precipitation of Wettest Quarter); Bio 17 (Precipitation of Driest Quarter and elevation).

\begin{tabular}{|c|c|c|c|c|c|c|c|c|c|c|c|}
\hline $\begin{array}{l}\text { AUC } \\
\text { mean }\end{array}$ & $\begin{array}{l}\text { Standard } \\
\text { Deviation }\end{array}$ & Threshold & Bio-3 & Bio-4 & Bio-7 & $\begin{array}{c}\text { Bio- } \\
10\end{array}$ & $\begin{array}{c}\text { Bio- } \\
11\end{array}$ & $\begin{array}{c}\text { Bio- } \\
14\end{array}$ & $\begin{array}{c}\text { Bio- } \\
15\end{array}$ & $\begin{array}{c}\text { Bio- } \\
16\end{array}$ & $\begin{array}{c}\text { Bio- } \\
17\end{array}$ \\
\hline 0.956 & 0.047 & 0.125 & 3.2 & 0.3 & 6.1 & 6.1 & 1.4 & 3.7 & 37.2 & 0.3 & 41.7 \\
\hline
\end{tabular}




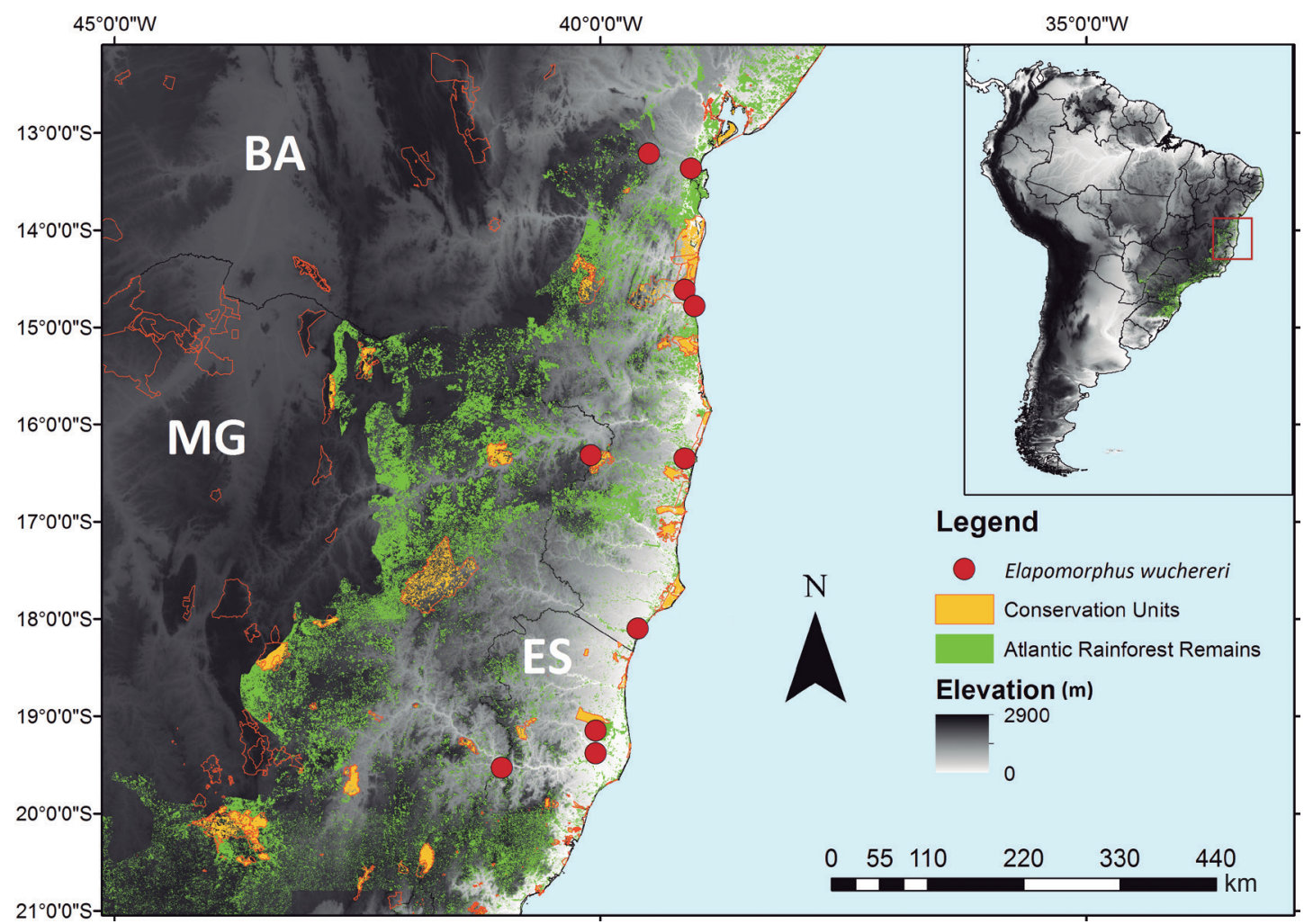

Figure 4. Geographic distribution records of Elapomorphus wuchereri. Orange patches are protected areas within remains of the Atlantic Rainforest. BA: Bahia state; ES: Espírito Santo state; MG: Minas Gerais state.

however, there are records in areas of low habitat suitability, such as western Espírito Santo, and northwestern and eastern Minas Gerais.

\section{Extent of Occurrence and Conservation}

Elapomorphus wuchereri is currently known from 10 municipalities and 13 vouchered individuals (Figure 4; Appendix I). The total extent of the species occurrence is $389,215.645 \mathrm{~km}^{2}$, but its range within the remaining Atlantic Forest is $56,055.892 \mathrm{~km}^{2}$ (i.e., $14.40 \%$ of its potential distribution). This range diminishes more if the strictly protected areas (known as "integral conservation units" in Brazil) that encompass $11,108.895 \mathrm{~km}^{2}$ (i.e., $2.85 \%$ of the potential range) are considered. Within the IUCN B criterion, the species meets two of the proposed conditions (VU B(a)), in having 10 known localities and (B.b (iii)) in having experienced a decline of both its range and quality of habitat; however, E. wuchereri does not meet the requirements for a threatened condition in $\mathrm{B} 1$ and $\mathrm{B} 2$ criteria.

We think that despite its wide distribution, $E$. wuchereri requires highly specific kind of habitat, and probably is restricted to wellpreserved and isolated patches of lowland Atlantic Rainforest. The scarcity of available records across a wide timeframe, virtually unknown population trends, and the possibility of extinction in some historical localities (e.g., the single record from Minas Gerais state) lead us to think that E. wuchereri should be assessed as a Data Deficient (DD) species. 


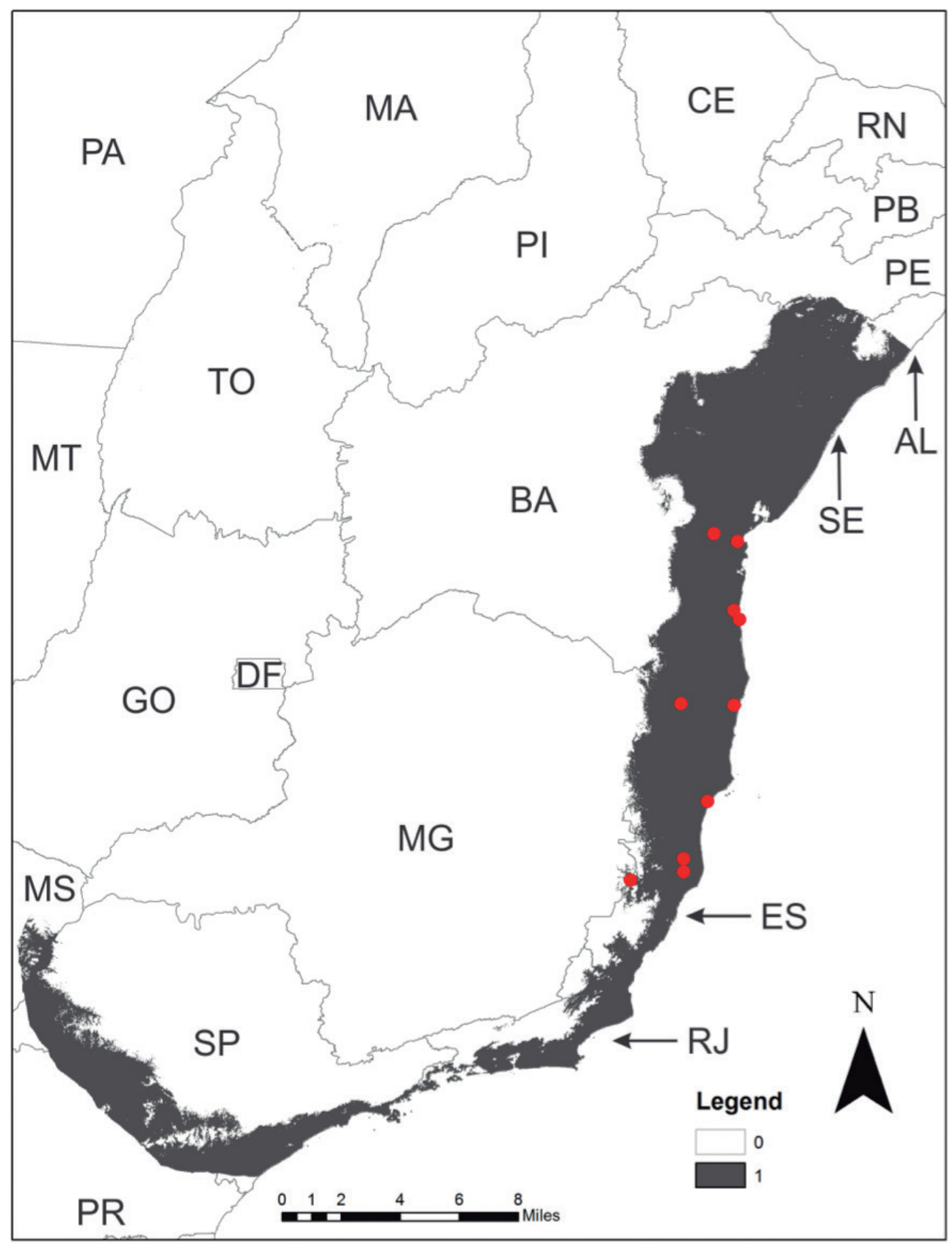

Figure 5. Binary presence (1) or absence (0) distribution suitability map, based on "Equal training sensitivity and specificity" threshold, for Elapomorphus wuchereri. Red circles represent records for the species. 


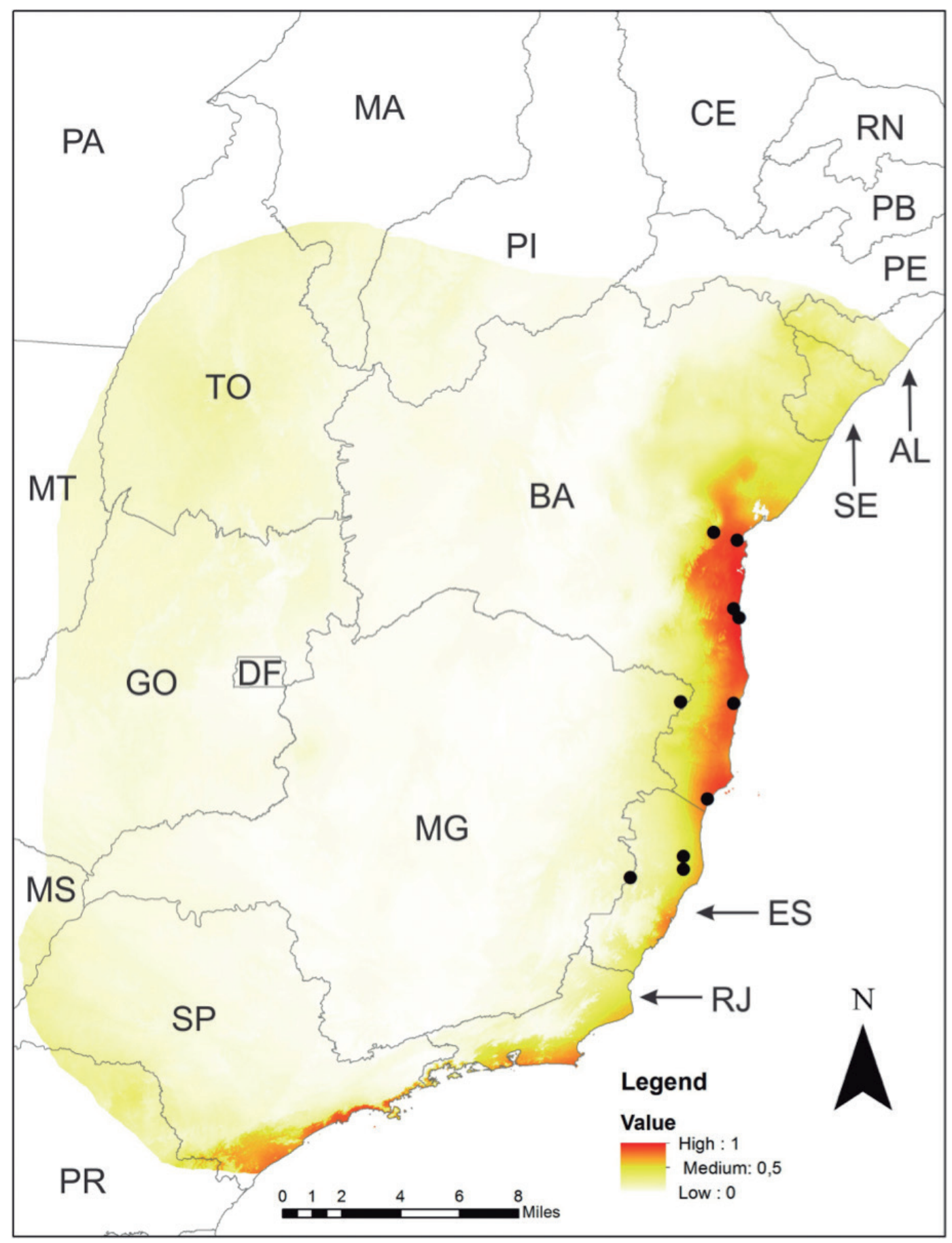

Figure 6. Species habitat suitability predictive distribution model of Elapomorphus wuchereri; darker colors indicate greater climate suitability. Black circles represent records for the species. 


\section{Discussion}

Elapomorphus wuchereri seems to be restricted to a small-sized patch of lowland Atlantic Rainforest, usually near the coast. Although suitable habitat is present at the northern and southern limits of its distribution in well-sampled areas, no such records have been recovered. The analyses conducted cannot be used to infer the causes of these absences; hypotheses to be considered are a high habitat specificity, climate sensitivity (which was found in other Atlantic Forest snake taxa by Moura et al. 2016), ancestral vicariant barriers, or competition with other species (such as E. quinquelineatus, a non-sympatric congener which occurs in much of the suitable habitat of E. wuchereri in Espírito Santo, Rio de Janeiro, and São Paulo states; Appendix I).

Although most individuals examined come from the Southern Bahia Endemism Center (sensu Barbo 2012), Elapomorphus wuchereri seems not to be restricted to this location, because its range reaches Minas Gerais and Espírito Santo. Other endemic species, such as Atractus guentheri (Wucherer, 1861), Bothrops pirajai Amaral, 1923 and Tropidophis grapiuna Curcio, Nunes, Argôlo, Skuk and Rodrigues, 2012, have their southernmost records restricted by the Jequitinhonha River (Passos et al. 2010; Curcio et al. 2012; Freitas et al. 2014). Our records also seem to fit within the biogeographical Subregions 2 and 3 outlined by Moura et al. (2016); these represent, respectively, the coastal or seasonal dry forests from northern Bahia to southern Rio de Janeiro states (in which the core distribution of the species is located), and the Serra do Mar Coastal, Bahia Coastal, and Interior Forests (3 records).

Our predictive model indicates that there are suitable habitats for Elapomorphus wuchereri in the coastal ranges of Rio de Janeiro and São Paulo-areas that have been extensively sampled but have no records of the species. One might surmise that because E. wuchereri seems to be cryptic and rare, it has not been found in these coastal areas. However, we doubt that the species occurs in São Paulo given the distance of São Paulo from the southernmost known records and the distinct biogeographical regionalization from the core distribution of the species (sensu Moura et al. 2016). It is also noteworthy that some records of voucher specimens from western Espírito Santo and northeastern Minas Gerais were recovered in low probability areas.

While the population trends of Elapomorphus wuchereri are unknown, it should be noted that only 13 individuals have been collected from 1861 to 2017, suggesting that the species has either, or both, a low population density or cryptic habits. In contrast, we found 187 specimens of its congener, E. quinquelineatus, which occupies cryptozoic habits, in the same collections. Given that the availability of climatically suitable areas for E. wuchereri (Figure 6) in its known range are restricted to a small coastal strip that has been highly deforested (Figure 4), we assume that the range of the species species has diminished along with the quality of the habitat. Because deforestation of the Atlantic Forest is largely irreversible, we assume that E. wuchereri experienced a severe population reduction and fragmentation.

The confusing taxonomic history of the Elapomorphini may have contributed to the limited number of specimens collected, and therefore, the lack of information about morphological variation. It is curious that so few specimens of E. wuchereri have been collected, despite the occurrence of the species in wellsampled regions of the Atlantic Forest. Based on our analyses, we suggest that $E$. wuchereri may be a threatened species; a Data Deficient (DD) category is suggested at present. It is imperative to conduct faunal inventories and search collections for new specimens to evaluate population trends, gene flux, and fragmentation in this species and thereby clarify its conservation status. 


\section{Acknowledgments}

We are grateful to Felipe Osmari Cerezer (UFSM) for his valuable help with the SDM software package analyses and appropriate methods. For the loan of specimens, photos, and data, we thank Antonio Jorge Suzart Argôlo (MZUESC), Christine Strüssmann (UFMT), Cyro Camargo Nogueira (IPSP), Franz Tiedemann (NMW), Garth Underwood (BMNH), Günther Peters (ZMB), Renato N. Feio and Henrique C. Costa (MZUFV), Iára Lúcia Laporta Ferreira (IBSP), Ivan Sazima (UNICAMP), Ilya S. Darevsky (ZIL), Marco Antonio de Freitas (UFPB), Mário Sacramento, Ulisses Caramaschi (MNRJ), and Vinícius Xavier da Silva (UNIFAL). We are indebted to Garth Underwood, Hobart Smith, and Collin McCarthy for their mentoring; to Wilhelm Shäfer (SMS director) and Axel Kwet for helping us to locate specimens; and to Henrique Caldeira Costa (MZUFV) for providing specimen data. Patrick Campbell and Jeffrey Streicher (BMNH) took high-resolution pictures of the neotype of $E$. wuchereri and syntypes of $C$. lepidus. Marco Antonio de Freitas, Mário Ribeiro de Moura, and Pedro Henrique Martins provided photographs of specimens of Elapomorphus and Coronelaps. We thank Saulo Rodrigues Pino for help with editing our plates. We are also thankful to Ross MacCulloch, Linda Trueb, and three anonymous reviewers.

\section{References}

Amaral, A. D. 1930a. Estudos sobre ofídios neotrópicos. XVII. Valor systemático de várias formas de ophidios neotrópicos. Memórias do Instituto Butantan 4: 3-68.

Amaral, A. D. 1930b. Contribuição ao conhecimento dos ofídios do Brasil. IV. Lista remissiva dos ophidios do Brasil. Memórias do Instituto Butantan 4: 71-125.

Amaral, A. D. 1930c. Estudos sobre ophidios neotrópicos. XVIII. Lista remissiva dos ophidios da região neotrópica. Memórias do Instituto Butantan 4: 129-271.
Amaral, A.D. 1935. Estudos sobre ophidios Neotropicos. XXXIII. Novas espécies de ophidios da Colombia. Memórias do Instituto Butantan 9: 219-223.

Amaral, A. D. 1936. Contribuição ao conhecimento dos ofídios do Brasil. VIII. Lista remissiva dos ophidios do Brasil. $2^{\mathrm{a}}$ edição. Memórias do Instituto Butantan 10: $87-162$.

Argôlo, A.J.S. 2004. As serpentes dos cacauais do Sudeste da Bahia. Ilhéus. Editora da UESC. 260 pp.

Barbo F. E. 2012. Biogeografia histórica e conservação das serpentes da floresta pluvial Atlântica costeira do Brasil. Unpublished Ph.D. Dissertation. Universidade Estadual Paulista Júlio de Mesquita Filho, Brazil.

Bérnils, R. S., A. P. Almeida, J. L. Gasparini, A. C. SrbekAraujo, C. F. D. Rocha, and M. T. Rodrigues. 2014. Répteis na Reserva Natural Vale, Linhares, Espírito Santo, Brasil. Ciência \& Ambiente 49: 193-210.

Boulenger, G. A. 1896. Catalogue of the Snakes in the British Museum of Natural History. Vol. 3. London. Trustees of the British Museum. 727 pp.

Curcio, F. F., P. M. Sales-Nunes, A. J. S. Argôlo, G. Skuk, and M. T. Rodrigues. 2012. Taxonomy of the South American dwarf boas of the genus Tropidophis Bibron, 1840 , with the description of two new species from the Atlantic forest (Serpentes: Tropidophiidae). Herpetological Monographs 26: 80-121.

Cunha, O.R. and F.P. Nascimento. 1978. Ofídios da Amazônia X: as cobras da região Leste do Pará. Publicações Avulsas do Museu Paraense Emílio Goeldi 31: 1-218.

Dowling, H.G. 1951. A proposed standard system of counting ventrals in snakes. British Journal of Herpetology 1: 97-99.

Dubois, A. 2000. Synonymies and related lists in zoology: general proposals, with examples in herpetology. Dumerilia 4: 33-98.

ESRI. 2014. ArcGIS. Professional GIS for the desktop. Version 10.2.2. Environmental Systems Research Institute, USA.

Ferrarezzi, H. 1993. Sistemática filogenética de Elapomorphus, Phalotris e Apostolepis (Serpentes: Colubridae: Xenodontinae). Unpublished M.Sc. Dissertation. Universidade de São Paulo, Brazil.

Freitas, M. A., A. J. S. Argôlo, C. Gonner, and D. Verissimo. 2014. Biology and conservation status of Piraja's Lancehead Snake Bothrops pirajai Amaral, 1923 (Serpentes: Viperidae), Brazil. Journal of Threatened Taxa 6: 6326-6334. 
Freitas, M. A. 2014. Squamate reptiles of the Atlantic Forest of northern Bahia, Brazil. Check List 10: 1020-1030.

Galindo-Leal, C. and I. G. Câmara. 2005. Status do hotspot Mata Atlântica: uma síntese. Pp. 3-11 in C. GalindoLeal and I. G. Câmara (eds.), Mata Atlântica: Biodiversidade, Ameaças e Perspectivas. Belo Horizonte. Fundação SOS Mata Atlântica, Conservação Internacional.

Günther, A. 1861a. Account of the reptiles sent by Dr. Wucherer from Bahia. Proceedings of the Zoological Society of London 1861: 12-18.

Günther, A. 1861b. Account of the reptiles sent by Dr. Wucherer from Bahia. Annals and Magazine of Natural History ser III 7: 412-417.

Hamdan, B. and R.J. Lira-da-Silva. 2012. The snakes of Bahia State, northeastern Brazil: species richness, composition and biogeographical notes. Salamandra 48: $31-50$.

Hofstadler-Deiques, C. and T. Lema. 2005. On the cranial morphology of Elapomorphus, Phalotris and Apostolepis (Serpentes: Colubridae), and its phylogenetic significance. Zootaxa 1042: 1-26.

Hijmans, R. J., S. E. Cameron, J. L. Parra, P. G. Jones, and A. Jarvis. 2005. Very high resolution interpolated climate surfaces for global land areas. International Journal of Climatology 25: 1965-1978.

Hijmans, R. J. and J. Elith. 2017. Species Distribution Modeling with R. Eletronic Database accessible at https://cran.r-project.org/web/packages/dismo/vignettes/ sdm.pdf. Captured on 11 March 2017.

Hijmans, R. J., S. Phillips, J. Leathwick, and J. Elith. 2013. Package 'dismo': Species Distribution Modeling. R package version 1.0-8. Eletronic Database accessible at http://CRAN.R-project.org/package=dismo. Captured on 11 March 2017.

IUCN. 2012. IUCN Red List Categories and Criteria. Version 3.1. Second edition. Gland and and Cambridge. International Union for Conservation of Nature. Eletronic Database accessible at htttp://www.iucnredlist. org/technical-documents/categories-and-criteria. Captured on 11 March 2017.

IUCN. 2014. Guidelines for using the IUCN Red List categories and criteria. Version 11. Prepared by the Standards and Petitions Subcommittee. Eletronic Database accessible at http://www.iucnredlist.org/documents/ RedListGuidelines.pdf. Captured on 11 March 2017.

Jan, G. 1862. Enumerazione sistematica della specie d'ofidi dei gruppo Calamaridae. Archivio di Zoologia, Anatomia ed Fisiologia della Universitá de Torino 2: 1-76.
Lema, T. 1984. Sobre o gênero Elapomorphus Wiegmann, 1843 (Serpentes, Colubridae, Elapomorphinae). Iheringia, Série Zoologia 64: 53-86.

Lema, T. and C. Hofstadler-Deiques. 1995. Estudo revisivo de Elapomorphus lepidus Reinhardt com a invalidação de E. wuchereri Günther, E. accedens Jan e E. coronatus Sauvage mediante análise tipológica e a osteologia craniana (Serpentes, Colubridae, Xenodontinae, Elapomorphini). Biociências 3: 91-143.

Lema, T. and C. Hofstadler-Deiques. 2010. Description of a new genus for allocation of Elapomorphus lepidus and the status of Elapomorphus wuchereri (Serpentes: Dipsadidae: Xenodontinae: Elapomorphini). Neotropical Biology and Conservation 5: 113-119.

Moura, M. R., A. J. Argôlo, and H. C. Costa. 2016. Historical and contemporary correlates of snake biogeographical subregions in the Atlantic Forest hotspot. Journal of Biogeography 44: 640-650.

Nóbrega, R. P., G. G. Montingelli, V. Trevine, F. L. Franco, G. H. C. Vieira, G. C. Costa, and D. O. Mesquita 2016. Morphological variation within Thamnodynastes pallidus (Linnaeus, 1758) (Serpentes: Dipsadidae: Xenodontinae: Tachymenini). Herpetological Journal 26: 165-174.

Passos, P., R. Fernandes, R. S. Bérnils, and J. C. MouraLeite. 2010. Taxonomic revision of the Brazilian Atlantic Forest Atractus (Reptilia: Serpentes: Dipsadidae). Zootaxa 2364: 1-63.

Peters, J. A. and B. Orejas-Miranda. 1970. Catalogue of the Neotropical Squamata. Part 1, Snakes. Bulletin of the United States National Museum 297: 1-347.

Phillips, S. J., R. P. Anderson, and R. E. Schapire. 2006. Maximum entropy modeling of species geographic distributions. Ecological Modelling 190: 231-259.

Phillips, S. J. and M. Dudik. 2008. Modelling of species distributions with Maxent: new extensions and a comprehensive evaluation. Ecography 31: 161-175.

R Development Core Team. 2008. R: a language and environment for statistical computing. Vienna. R Foundation for Statistical Computing. Eletronic Database accessible at http://www.R-project.org. Captured on 11 March 2017.

Strauch, A. 1884. Bemerkungen über die Schlangengattung Elapomorphus aus der Familie der Calamariden. Mélanges Biologiques de l'Académie Impériale des Sciences du Saint Pétersbourg 12: 141-211.

Editor: Ross D. MacCulloch 


\section{Appendix I. Specimens examined.}

Abbreviations: Acc, according to; a.s.l., above sea level; WI, without indication of locality; WN, without number.

Coronelaps lepidus: BRAZIL: WI (NMW 21989, 21995). BAнIA: Banco do Pedro (MZUSP 9610); Ilhéus: Rio Ilhéus (BMNH 1946.1.3.1, BMNH 1946.1.2.92, ex-syntypes of E. wuchereri), Ribeirão Fortuna (MNRJ 2948). CEARÁ: Crato: Floresta Nacional do Araripe (MNRJ w/n, probably in error). EsPírito SANTO: WI (ZSBS w/n, UFES-CZ A-105); Marechal Floriano: Araguaia: Vila Domingo Martins (IBSP 28891, IBSP 29494); Araguaia (IBSP 9302, IB 10425, IBSP 10534. IB 20762); Campinho (MNRJ 2987); Marechal Floriano (MCP 9196); Rio Doce (MZUSP 96); Santa Tereza (MNRJ 741a, MNRJ 741b, MNRJ 2975). Minas Gerais: Caratinga (IB 324-325); Iripui (IB 16022); Muzambinho (IB 9839); Ouro Preto (IB 854, 12963); Rio Casca: Arraial do Bicudo (MZUC 63821, holotype); São Sebastião do Paraíso (IB 915). ParaíBa: Pico do Jabre (MNRJ w/n). Rio de Janeiro: Nova Friburgo (IB 21930); Rio de Janeiro (MNHN 5073, holotype of E. coronatus), Corcovado (MNRJ 2986); Teresópolis (IB 740, IB 48501, FMNH 9028). SÃo PAUlo: Serra da Bocaina (ZUEC 1377).

Elapomorphus wuchereri: BRAZIL. BAHIA: Ilhéus: Rio Ilhéus, Fazenda Cacao (BMNH.1946.1.2.91, neotype; BMNH.1946.1.2.96, topotype); Salto do Apepique: RPPN (UESCB.4288). Mutuipe: Fazenda Segredo do Fogo (UESCB.1457). Porto Seguro: Santa Cruz de Cabrália, Reserva Florestal Veracruz (IB.55983). São Bento das Lagoas (unknown locality; ZMB. WN); Rio Mucuri: Fazenda Pombal (ZUEC.240). Essírito Santo: WL (MBES.77); Baixo Guandu (IB.8825); Linhares (MZUSP.9837). Minas Gerais: Santa Maria do Salto (MZUFV.1205).

Elapomorphus quinquelineatus: BRAZIL: WI (MZUT, WN; ZMB.324; ZIL.1415, ZIL.1487; ZMB.1920, ZMB.2169.0; ZIL.2547; MNHN.3673, paratype); Guyana (USNM.6180, Peters, 1869, In Error); ZIL.6233, ZMB.21680, MNRJ.3366a-f; NMW.13803, NMW.21997; IB.22642). EsPíRito SANTo: WI (MBES.401; MZUSP. WN; ZMB WN). Santa Teresa, Reserva Florestal (MNRJ.742; MNRJ.743, at $750 \mathrm{~m}$ a.s.1.; MNRJ.744; MNRJ.745 at $750 \mathrm{~m}$ a.s.1. AOR to Itaguaçu; MNRJ.747 at 790 m a.s.1., AOR; MNRJ.749, 750 m a.s.1. AOR; MNRJ.1286, 700 m a.s.1., AOR; Santa Teresa (MNRJ.746, 680 m a.s.1., AOS; MNRJ.748, 750 m a.s.1., AOG; Cariacica (IB.1018); Araguaia (IB.9273, IB.10057, IB.20763). Fundão (IB.30662). RIO DE JANEIRO: WL (MZUM.65879b, NMW.20718.1, NMW.20718.2, IB.4483, IB.6514). Rio de Janeiro (BMNH. 2 specimens, acc. Boulenger, 1896): Corcovado railway (NMW.20719.1), Complexo da Maré, Vila Pinheiro (IB.112), Jardim da Saudade (IB.549), Tijuca (IB.795; BMNH. one specimen, acc. Boulenger, 1896), Tijuca, Alto da Boa Vista (MCN.9498, MCN.9499), Vargem Grande (IB.5616, IB.10321), São Cristóvão, Zoological Park (IB.1351), Santa Teresa (MNRJ.2706a-d, MNRJ.2975, IB.5864, IB.45806), Jacarepaguá (MNRJ.2638), Morro da Urca (IB.2581), Areal (IB.9392), Barão Homem de Melo (IB.10396), Barão de Vassouras (IB.6537); Barra Mansa: Floriano (IB.9745); Barra do Piraí (IB.16698), Ipiabas (IB.5643; IB.7076); Duque de Caxias (MNRJ.2066, MNRJ.2968, MNRJ.2866a, MNRJ.2866d), Sarapuí (MNRJ.750); Engenheiro Paulo de Frontin: Morro Azul (IB.9473); Itatiaia (MNRJ.751, MNRJ.3549): Parque Nacional do Itatiaia (IB.25621): Mendes (IB.1556, IB.7339, IB.9404, IB.16025); Macaé: Piracema (IB.16024); Natividade (Historically known as Natividade de Carangola), S. José farm (MCN.9500); Nova Friburgo (IB.942); Porto Real (BMNH, acc. Boulenger, 1896); Resende (IB.10395); Rio Claro (IB.9808, IB.10045); Sapucaia (IB.31447); Quatis: Joaquim Leite (IB.7819, IB.8515); Teresópolis (BMNH, acc. Boulenger, 1896; MNRJ.2879); Valença: Conservatório (IB.8611, IB.9008), Esteves (IPSP.1720), Quirino (IB.8370, IB.12334); Volta Redonda (IB.9471, IB.9728). MinAs GERAIS: WL (MZUSP WN; IB.9591). Antônio Carlos (IB.27963); Caiana (IB.25976a-b); Cataguases (IB.1287, IB.1290), Sereno (IB.8833, IB.9004); Conceição do Mato Dentro: Três Barras (IB.4591); Divinópolis (IB.32065); Extrema (IB.5432, IB.8255, IB.8334, IB.9673); Guaxupé (IB.1454); Juiz de Fora (IB.25817, IB. 27173, IB.29433, IB.30943, IB.32130, IB.33045, IB.33048a-c), Creosotagem (IB.770); Matias Barbosa: Cedofeita (IB.113a-c); Passa Vinte (IB.9481, IB.9519, IB.9572, IB.9656); Poços de Caldas (IB.7259, IB.10483a, b; IB.17092); Resplendor: Campo Alegre (IB.2553); Santo Antonio do Retiro (IB.899, IB.913); Ubá (IB.33583): Viçosa: Faculdade de Agronomia (MNRJ.752-758); Virginópolis, Serra do Cipó (FUNED.71). São PaUlo: WL (MCZ.20768, MCZ.27663; RMNH.124a-b, syntypes of Calamaria blumii Schlegel 1837, neotype and paratype respectively, of E. quinquelineatus). Águas da Prata: Cascata (IB.607, IB.769); Bananal (IB.8269); Bauru (IB.10506); Bebedouro (IPSP.963); Cabras (unknown locality, IB.5549); Corumbataí: Atalaia (IB.8521); Guaratinguetá (IB.15794, IB.17982, IB.21671); Guarujá: Perequê (IB.4909); Jaboticabal (IB.5285); Lavrinhas (IB.14365); Mogi das Cruzes (IB.31938); Morro Agudo (IB.5501); Paranapiacaba: Alto da Serra, Estação Biológica (IB.1705); Penápolis (USNM.7337.1, USNM.7337.2); Pindamonhangaba (IB.30410); Piquete (IB.449, IB.6483), Fazenda Santa Lídia (IB.43039); Poá (IB.18783); Quirino (unknown locality, IB.8844); São José do Rio Preto (IB.7351); São José do Barreiro (IB.42450); Serra da Cantareira, Romanasa County: Jardim da Montanha (IB.40689); Taubaté (IB.111, IB.2142, IB.3270); Vale do Parnaíba (IB.6305). Santa Catarina: Criciúma, coal rejects region (MCN.6305). Rio Grande do Sul: WL (NMW.21996, In Error). Canguçu (IB.52713, In Error); Sapucaia do Sul: Anta (IB.31447). 